\title{
Steps of the Development and Formation of Regulatory and Legal Framework for State Youth Policy in Uzbekistan
}

\author{
Holmahmatov Azim, Toshov Khurshid, Khojiev Tunis
}

\begin{abstract}
The article analyzes the problem of rounding the processes of formation of the state youth policy in Uzbekistan as a theoretical source of the legislative and legislative acts of the Republic of Uzbekistan in this field. This is due to the fact that these normative documents define the content of a number of concepts that serve as a category system for research in the field. It also reveals that the period of formation of the state youth policy in Uzbekistan is considered as a determinant of the date of adoption of the Law and other legislative acts.
\end{abstract}

Keywords: Youth Policy, Youth Social Movement of Kamolot, Law Educators, Thinking Tests, Youth Union, Fund for Development, determinand, State Youth Policy Act.

\section{INTRODUCTION}

The issue of legal regulation of state youth policy is one of the essential aspects of its development and implementation in political processes. It is the legislative level that determines the possibility of establishing effective organizational and managerial mechanisms for the implementation of the state youth policy.

We will study the stages of their development and formation in order to get a complete picture of the legal basis of the state youth policy in the Republic of Uzbekistan. At that time, this process was regulated by subordinate documents of the ministries and agencies of the former Soviet Union at the level of decisions of the Council of Ministers of more than 1,300 [1].

The Communist Youth Union was a powerful public association with all the practical resources needed to work with young people. Because of this, it has strong links with trade unions and public authorities, which can also be described as an organization that implements the state youth policy of the former Soviet Union and coordinates the activities of state bodies involved in it [2].

After gaining independence, along with many other areas, the state youth policy of the Republic of Uzbekistan has been radically reorganized as a separate direction and has undergone a number of important evolutionary stages. There are thousands of examples of their courage. The new

Revised Manuscript Received on October 15, 2019.

Holmahmatov Azim, Senior Lecturer (PhD) of the National University of Uzbekistan named after Mirzo Ulugbek, Uzbekistan.(email: a.holmahmatov@nuu.uz)

Toshov Khurshid, Senior Lecturer $(\mathrm{PhD})$ of the National University of Uzbekistan named after Mirzo Ulugbek, Uzbekistan.(email: h.toshev@nuu.uz)

Khojiev Tunis, Senior Lecturer $(\mathrm{PhD})$ of the National University of Uzbekistan named after Mirzo Ulugbek, Uzbekistan.(email: x_tunis@nuu.uz). generation has come up with a vibrant feeling of "I serve my motherland", studying our spiritual heritage, following our traditions, adhering to our thinkers and scholars, singing the national anthem, proud of our nation's flag, proud of ancestors. [3].

\section{REVIEW OF THE LITERATURE ON THE TOPIC}

The theoretical sources are the ideas put forward in the speeches of the First President of the Republic of Uzbekistan [4], the works of the President of the Republic of Uzbekistan, and their conceptual and practical proposals to further improve the state youth policy in Uzbekistan.

Moreover, works on the analysis of the issues related to youth policy carried out during the years of independence in Uzbekistan are: K. Kuranbayev, S. Juraev, D. Buronova, F. Ravshanov, M. Yuldashev, Z. Kadirova, E. Boboburodov, G. Tulenova's research and scholarly works of renowned scholars. In this regard, the study of the issue of further deepening of democratic reforms in the country as a special object of research is based on the Strategy of development of Uzbekistan for 2017-2021. the development of conclusions and suggestions needed for practice requires special attention.

\section{RESEARCH METHODOLOGY}

During the research, sociological methods were used such as objectivity, historicity, comparative-historical, structural, structural-functional, analysis and synthesis, induction and deduction, document study, data processing grouping.

\section{ANALYSIS AND RESULTS}

The process of formation and implementation of the state youth policy in Uzbekistan can be divided into two chronological stages in connection with the adoption of two important laws.

The first stage, including 1991-2016, can be characterized by a number of peculiarities, including the implementation of state youth policy, its separation and institutionalization as a particular priority of state political activity. 
The beginning of this phase is marked by the adoption of the Law of the Republic of Uzbekistan "On the Basis of State Youth Policy in the Republic of Uzbekistan" on November 20, 1991. The adoption of this law also promoted the widespread use of the term 'State Youth Policy' in the wider scientific and practical context. From this date to the present, the youth policy in the Republic has acted as a special type of political activity.

The adoption of the law has led to the emergence of state bodies and the State Council for Youth Affairs, which are involved in public youth policy. According to the law, the youth policy is the priority of the state activity of the Republic of Uzbekistan, the purpose of which is to create and guarantee the socio-economic, legal and organizational conditions for the social formation and development of young people, the full realization of their creative potential for the benefit of society. [7].

In this regard, during the democratic transformations in the country, special attention is paid to the physically sound and spiritually mature generation, to provide it with the most up-to-date intellectual knowledge, to further enhance and strengthen the level of education. At the same time, the main tasks in this area have been identified as providing the youth with greater opportunities in the life of the state and the people, creating the necessary conditions for their stable and worthy place in society.

Special attention is paid to the involvement of young people in the socio-political processes and their active participation in democratic renewal processes. In this process,it is described that young people should "become people who understand their national identity, but also the world, step by step" by the First President of the Republic of Uzbekistan [8], that is why young people have been described not only as a subject but also as a subject of state youth policy.

At that time the independence of Uzbekistan, along with all other spheres of life, provided ample opportunity for reforms and renewal in this area, has become an important component of the state policy. The following statement of the first President Islam Karimov in the early years of independence is the most important theoretical conclusion in the definition and understanding of the main goals and priorities of the state youth policy: “... To safeguard the hearts and minds of our young generation, to educate them in the spirit of national and universal values, to have a deep understanding of the essence and underlying causes of political processes occurring in the world, and most importantly, independent information about what is happening around them and, that is, the ability to distinguish whites from blacks should be a prerequisite and criterion for our educational and spiritual work. "[9]

Based on this conclusion and on the basis of the requirements of that time, a special emphasis was placed on the youth problem in our country, and the creation of ample opportunities for meeting their interests and needs. It also identified urgent tasks needed for the gradual and systematic implementation of the strategic directions of our state on youth issues and identified a number of state and non-state organizations that will ensure the implementation of these tasks. It is clear from the earliest stages of institutionalization of state youth policy in Uzbekistan that research shows that young people and a number of state and non-governmental organizations have been identified as subjects of state policy in this area.

In the first stage of implementation of the Law "On the Basis of State Youth Policy in the Republic of Uzbekistan", defined by 1991-2016, this law ensured the formation and effective functioning of the state youth policy. It is precisely this fact that this historic document, adopted in Uzbekistan among the former Soviet republics, set the main priorities and priorities in the state youth policy of the main reformer.

At that time, this law outlined some principles regarding education, protection of youth participation in international relations, working with minors, and supporting talented youth [10]. They are also reflected in a number of legal acts in the field of the state youth policy of the Republic of Uzbekistan.

In particular, the laws of the Republic of Uzbekistan "On Education", "On the National Program for Personnel Training", "On measures to encourage young people studying in Uzbekistan", "Improvement of the system of advanced training of teachers and researchers" and "Improving the reproductive health of the population in 2009-2013 of the Program of Measures for Increasing Efficiency and Efficiency ", a number of regulations such as "On additional measures to further strengthen the material and technical basis and development of football in the Republic in 2011-2013" will help young people find their place in life, actively participate in the socio-political processes in the country and in the formation of civil society played an important role in increasing their contribution.

From the first day we relied on the younger generation to carry out these tasks consistently. Their role as participants in democratic renewal processes has been further enhanced by the involvement of young people in the socio-political processes and their active participation in reforms. It is defined by:

- In the new age, it has become clear that there is a common law in relation to youth, that is, youth has now become the dominant force that determines the progress of society from a relatively dominant person;

- the social qualities of young people, such as intellectual abilities, professionalism, spiritual and spiritual development, have had a positive impact on the development of the whole society. Such trends show that young people become active subjects of politics as a separate social demographic stratum.

Published By:

Blue Eyes Intelligence Engineering

\& Sciences Publication 
Taking into account these factors, the first President IA Karimov said: "The issues of working with youth require special attention. It is very important today to further enhance the role and place of young people in the society. "[11]

In general, youth policy has been developed in some developed countries in the 1960s and '70s as an independent industry. However, this issue became more relevant after the UN General Assembly adopted a resolution on the basic principles of effective youth policy in 1985, L. Tangriev wrote in his Ph.D. In each country, different mechanisms and systems for the implementation of youth policy, in accordance with their specific system of state building and management, have begun to emerge.

From this point of view, the independence of the Republic of Uzbekistan is an important stage in the state youth policy and it opens wide opportunities to pay special attention to youth problems in politics.

In accordance with the Decree of the President of the Republic of Uzbekistan dated February 6, 2014 "On additional measures to implement the state youth policy in the Republic of Uzbekistan" a special state program was adopted. In order to ensure full and qualitative implementation of this Program, timely implementation of the tasks, an action plan for implementation of the Program of additional measures to implement the state youth policy in the Republic of Uzbekistan for 2014 was developed. This plan consists of 7 chapters, 76 paragraphs, which cover the tasks that should be carried out in different directions within the plan.

The system has implemented a number of systemic measures aimed at improving the political and legal literacy of young people. In particular, holding national contests such as "Legal scholars", "Do you know the law?" And "Thinking tests" aimed at improving the legal literacy of students and students of educational institutions of the country shows young people not only an opportunity to evaluate their knowledge, but also their aspirations. The fact that more than 5700 young people participated in the online contest "The Connoisseur of Parliamentarism-201" [13] on the official website of the Legislative Chamber of the Republic of Uzbekistan shows that the work has been successful.

The period of time has shown that perfect legislation is the main factor in the creation of a democratic and democratic state. On this basis, it becomes necessary to develop a system of laws, ranging from the system of governance to the smallest spheres of our multidimensional life [14]. Where the law is perfect and the moral and ethical world of the population is mature, people continue to govern themselves. High spirituality and the rule of law become a way of life.

In this way, the activities of the state and governing bodies are radically changed, the governing functions of the state rests with the self-governing bodies, public organizations, or, as the first President put it, "The legal state is the weapon, the protection, the eyes and the word."

These words not only raise the legal awareness of the people of our country, but also raise the younger generation in the spirit of high spiritual values and best traditions, deepen our sense of responsibility for the fate of our country, its future and tomorrow, and reform and renewal of all aspects of our lives. It requires that they strive to achieve great success in study, in order to contribute to accelerated work.

\section{RESULTS \& DISCUSSIONS}

It is evident that during this period the social, economic, spiritual and especially legal basis of the state youth policy has been constantly strengthened.

One of the greatest achievements in the history of our national statehood is the particular attention paid to youth policy in this area.

Taking this into account, the first stage of the formation and implementation of the state youth policy of the Republic of Uzbekistan can be carried out in four chronological steps according to the formation of entities that will implement this policy.

The first period, including 1992-1996, was the main subject of the state youth policy. It is based on membership and operates at the expense of membership fees.

Youth Union of Uzbekistan,firstly, bureaucratic duties such as collecting dues from members, keeping them accountable, and maintaining card accounts;

Secondly, the organization deals exclusively with politics and ideology and follows the former Komsomol organization;

Thirdly, Uzbekistan's Youth Union has not been able to move fast in transition to a market economy.

The aforementioned and similar shortcomings have led to the question of revision of the organization's activities.

During the transition to the market relations of our country, a number of needs have emerged, including social support for youth, entrepreneurial skills, and the release of addiction. As a result, the second stage of the formation of the state youth policy, 1996-2001, began. During this period, the "Kamolot" Fund was established as the main executor of the state youth policy. 
The fund was established in accordance with the Decree of the President of the Republic of Uzbekistan dated April 17, 1996 "On Kamolot Fund of Youth of the Republic of Uzbekistan" No. P-1425 [17]. The activity of the organization was strengthened by the Resolution of the Cabinet of Ministers of the Republic of Uzbekistan dated May 31, 1996 № 207 "On support of the Kamolot Fund of Youth of the Republic of Uzbekistan".

The organization was not affiliated with the program and operated under the savings departments at the expense of government-approved subsidiaries (they were exempt from state tax for up to 5 years).

In its turn, the Kamolot Foundation has not been able to meet the requirements of the time. This was the third phase of the formation of a state youth policy in Uzbekistan in 2001-2006.

During this period there was an opportunity to implement the tasks set in the Program and Charter of the Kamolot Youth Social Movement, strengthen the financial and economic basis and material and technical basis of the Movement. There was no membership fee, no membership cards, and no ideological duties. The Kamolot Youth Social Movement of Uzbekistan was established as a voluntary, self-governing, non-profit organization for the youth of Uzbekistan.

The Decree of the President of the Republic of Uzbekistan on PQ-486 of October 2006 "On support and further increase of effectiveness of the Kamolot Youth Social Movement" [19] began a new era and marked the effectiveness of the reform and effectiveness of the Kamolot Youth Social Movement. This fourth period, which has played an important role in the growth of the global economy, covers 2006-2016.

During this period the Cabinet of Ministers of the Republic of Uzbekistan, khokimiyats of the Republic of Karakalpakstan, provinces and Tashkent city, ministries and agencies in the field of spiritual and educational sphere should resolve the issues of youth, above all, neglect, neglect and irresponsibility. The main task is to strengthen social activity of new generation. In this regard, the task of relying on the Kamolot Youth Social Movement has been identified as an important area of activities of these government agencies.

In general, at the first stage of the formation of the state youth policy in Uzbekistan, the specific organizational and legal framework for this policy has been developed and constantly improved.

The result is a specific way of implementing state youth policy in the country, naming the years (1998 Family Year, 2000 Year of Healthy Generation, 2001 Year of Mother and Child, 2008 Year of Youth, 2010 Year of Harmonious Generation, 2012 Adoption of the programs of the Family Year, 2014 Year of the Healthy Child and 2016 - the Year of the Healthy Mother and Child, and from 2012 ("Additional
Measures for the Implementation of the State Youth Policy in the Republic of Uzbekistan"). A system of practical implementation has been formed.

The second stage began with the adoption of the Law of the Republic of Uzbekistan "On State Youth Policy" [20], adopted on September 14, 2016. The adoption of this law has opened a new era in the field of state youth policy in Uzbekistan.

In its turn, it contributes to strengthening the rights and lawful interests of young people in the country, enhancing the responsibility and cooperation of state bodies and other organizations in the implementation of the state youth policy, as well as raising the effectiveness of measures aimed at fostering a healthy and harmoniously developed generation.

According to this law, the criteria for the state youth policy are set in line with today's requirements. Most importantly, the law defines the social, economic, political and other rights and interests of young people as priority areas of social policy in this area.

On this basis, Uzbekistan will develop easy-to-implement scientific and theoretical approaches and methods to work with young people, increase their political, legal awareness and culture, actively involve them in political processes, develop youth entrepreneurship, and improve financial mechanisms for the implementation of youth policy.

One of the important aspects of the law is that the basic concepts in this area are explained in the following directions: "state youth policy", "youth (young citizens)", "and young family", "young specialist” [21].

The law clearly defines the subjects pursuing the state youth policy. The law also provides for social, economic and political benefits for young people.

A number of legal, organizational, project and financial mechanisms are being developed in order to implement the main directions of state youth policy in Uzbekistan as outlined in this law. In particular, following the meeting of the President of the Republic of Uzbekistan with the youth held on June 30, 2017, 40 laws and regulations were adopted in the field of youth policy.

In particular, three laws of the Republic of Uzbekistan were adopted. In addition, by the Decree of the President of the Republic of Uzbekistan dated July 5, 2017, PF-5106 "On Enhancement of the Effectiveness of the State Youth Policy and Support of the Youth Union of Uzbekistan", about 70 legal acts on youth has been amended.

Blue Eyes Intelligence Engineering

$\&$ Sciences Publication 
At the same time, 5 Decrees, 8 Resolutions, 2 Orders of the President of the Republic of Uzbekistan, 18 Resolutions and 4 Decrees of the Cabinet of Ministers of the Republic of Uzbekistan are the basis for systematic, step-by-step implementation of youth policy reforms.

In accordance with the Decree of the President of the Republic of Uzbekistan "On Enhancement of Effectiveness of the State Youth Policy and Support of the Youth Union of Uzbekistan", adopted by the President of the Republic of Uzbekistan with the aim of radical improvement of activities in this area. For the purpose of radical reforming of the system of comprehensive support, protection of rights and legitimate interests of Uzbekistan, on the basis of Kamolot Youth Social Movement of Uzbekistan Youth Union of the Karakalpakstan [23].

The day of establishment of the Union of Youth of Uzbekistan - June 30 is celebrated in our country as the Youth Day [24].

The Youth Union of Uzbekistan has been assigned a number of new and important tasks related to increasing youth activity in the framework of the Strategy of Action for the five priority directions of development of the Republic of Uzbekistan in 2017-2021.

\section{CONCLUSIONS}

In general, the process of formation and implementation of the state youth policy in Uzbekistan can be studied in two stages. The laws of the Republic of Uzbekistan in the field of state youth policy are defined in this chronological period. The peculiarities of the first stage are the emergence of the state youth policy in Uzbekistan as an independent activity, the formation of its legal and organizational framework and the formation and development of youth policy. The second stage can be characterized by a clear definition of the state youth policy, the identification of priorities and principles, the determination of state and nongovernmental organizations implementing state youth policy, and the improvement of mechanisms and technologies for the implementation of state youth policy.

In conclusion, the first stage can be considered as a period of formation and institutionalization of the state youth policy in the Republic of Uzbekistan, and the second stage can be regarded as a period of widespread penetration into all youth segments.

\section{REFERENCES}

1. Slutsky, E.G. How does politics matter? / E.G. Slutskiy // Molodej: digits, facts, mneniya. -SPb., 2006.-No.1-S. 1819.

2. Shiryaev EB Novoe v ideyno-politicheskom vospitanii molodeji. Комсомол и развитие молодежного движения in the USSR: sushchnost, problematic and modern tendency / EBShiryaev, A.V. Aleynikov. - L., 2000. - p. 54.

3. Alimardoniov T. "The Generation of Freedom" http://www.biznes-daily.uz

4. Karimov I.A. Further deepening of democratic reforms and development of civil society is the main principle of the country's development. - T. 19. - Tashkent: Uzbekistan, 2011. - 292 b; Uzbekistan is on the threshold of gaining independence. - Tashkent: Uzbekistan, 2011. $383 \mathrm{~b}$.

5. Mirziyoev Sh.M. Together we will build a free and prosperous, democratic Uzbekistan. - Tashkent: Uzbekistan, 2016; The rule of law and the protection of human interests are the key to the country's development and prosperity. - Tashkent: Uzbekistan, 2017; Critical analysis, strict discipline and personal accountability should be the daily routine of each leader's activities. Tashkent: Uzbekistan, 2017; We build our great future with our brave and noble people. - Tashkent: Uzbekistan, 2017.

6. Law of the Republic of Uzbekistan No. 429-XII "On the basis of the state youth policy in the Republic of Uzbekistan"

http://www.lex.uz/search/all?form_id=3968\&fyear=1991

7. Article 1 of the Law No. 429-XII "On the basis of the state youth policy in the Republic of Uzbekistan" http://www.lex.uz/acts/140894

8. Karimov I.A. High spirituality is an invincible force. $-\mathrm{T}$ .: Spirituality. 2008.P - 119 .

9. Karimov I.A. It is our highest goal to ensure gradual and sustainable development of our country. - T . NUU "Uzbekistan", 2009. T.17. - B.131.

10. Article 7 of the Law of the Republic of Uzbekistan "On the Principles of Youth Policy in the Republic of Uzbekistan" http://www.lex.uz/acts/140894

11. Karimov I.A. "Uzbekistan seeks for 21st century." Tashkent: Uzbekistan, 1999, p.23

12. Tangriev K. Candidate's dissertation on "Youth policy subject: employment problem". Auto-abstract. Tashkent: 2001.

13. www.parliament.gov.uz

14. Juraev N. The concept of renewal: creation, evolution and practice. - T .: Spirituality, 2002. - P. 43.

15. Karimov I.A. Box 20, Our Way - The Way to Deepen and Enhance Democratization Reforms. T:, "Uzbekistan" 2012, page 140 .

16. Stormova D. "Youth Policy in Uzbekistan: Basic Principles and Their Meaning" - T .: Gafur Gulom, 2008. p. -82

17. "Kamolot" Youth Fund of Uzbekistan. Decree of the President of the Republic of Uzbekistan // Public speech. April 18, 1996.

18. "Kamolot" Youth Social Movement of the Republic of Uzbekistan. Collection of documents related to the decision of the Cabinet of Ministers of the Republic of Uzbekistan from May 30, 2001 № 240. -T .: 2001.

19. Resolution of the President of the Republic of Uzbekistan No. PP-486 dated October 10, 2006 "On support and further increase of efficiency of the Kamolot Youth Social Movement" // Public speech, October 10, 2006.

20. Regulatory and legal documents on the activities of the Youth Union of Uzbekistan (Part I). - T: "Uzbekistan" NMIU, 2017.P - 32.

21. Regulatory documents on the activities of the Youth Union of Uzbekistan (Part I). - T: "Uzbekistan" NMIU, 2017.P - 32.

22. Regulatory documents on the activities of the Youth Union of Uzbekistan (Part I). - T: "Uzbekistan" NMIU, 2017.P - 59. 
23. Comment on the Decree of the President of the Republic of Uzbekistan "On Enhancement of Effectiveness of the State Youth Policy and Support of the Youth Union of Uzbekistan" http://lex.uz/docs/3255680

24. Regulatory and legal documents on the activities of the Youth Union of Uzbekistan (Part I). - T: "Uzbekistan" NMIU, 2017.P - 58.

25. Decree of the President of the Republic of Uzbekistan dated February 7, 2017 "On the strategy of further development of the Republic of Uzbekistan" // Public speech, February 8, 2017. 